\title{
THE DEFEASANCE OF ESTATES ON CONDITION
}

\author{
HAROLD M. BOWMAN \\ Professor of Law, Boston University \\ I. THE NATURE OF DEFEASANCE IN GENERAL
}

The operation and effect of the defeasance of an estate on condition are expressed by Littleton in these words:

"Then may the feoffor or his heires enter into such lands or tenements, and them in his former estate to have and hold, and the feoffee quite to ouste thereof. And it is called an estate upon condition because that the estate of the feoffee is defeasible, if the condition be not performed, \&c."1

"In the same manner it is if the lands be given in taile, or let for terme of life or of yeares, upon condition, \&c."?

The defeasance as thus expressed is the abrupt termination and displacement of one estate by a physical act; and this act, subject to a few exceptions, clothes the person performing it with a former estate in the property.

Littleton's statement has stood the test of time, and its precision and adequacy are attested by the fact that the words in which modern decisions and text-books describe the operation of the defeasance do not vary in any essential respect from his own. ${ }^{3}$

It has always been admitted that when the interest conveyed is a freehold on condition-whether in fee, in tail, or for life, and whether the interest be corporeal or incorporeal-entry or its equivalent is necessary unless the person entitled to the benefit of the condition is himself in possession. In the case of interests such as reversions or remainders, rents or commons, which do not lie in livery and of which there can be no entry or possession, there must be a claim. Yet this claim is very much the same thing as entry. In the ordinary case it must be made upon the land.* Thus Coke points out that in the case of an advowson, the claim must be made at the church. He illustrates as follows:

"As if a man grant an advowson to a man and his heirs upon condition that if the grantor, \&c. pay 20 pound on such a day, \&c. the state

${ }^{1}$ Co. Lit. 325. The first American edition of Coke upon Littleton (Phila. I853) is referred to throughout the present article.

${ }^{2}$ Co. Lit. 326.

'Leake, Prop. in Land (2d ed.) I68; Gray, Perpetuities (3d ed.) s. 312; Tiffany, Real Prop. 180; Jenks, Dig. of Eng. Civil Law, s. I052 n.

Co. Lit. $218 a$. 
of the grantor shall cease and be utterly void, the grantee payeth the money, yet the state is not revested in the grantor before a claim, and that claim must be made at the church."

When the grant is a public one, or by a corporation, the enforcement must be representative.

"If the grant be a public one," says Mr. Justice Field in Schulenberg $v$. Harriman," "it must be asserted by judicial proceedings authorized by law, the equivalent of an inquest of office at common law, finding the fact of forfeiture and judging the restoration of the estate on that ground, or there must be some legislative assertion of ownership of the property for breach of the condition, such as an act directing the possession and appropriation of the property, or that it be offered for sale or settlement. At common law the sovereign could not make an entry in person, and, therefore an office-found was necessary to determine the estate, but, as said by this court in a late case," 'the mode of asserting or of resuming the forfeited grant is subject to the legislative authority of the government. It may be after judicial investigation, or by taking possession directly under the authority of the government without these preliminary proceedings." "

If to-day the maintenance of an action in the nature of ejectment without entry often takes the place of actual entry, certainly by this evolution-for the process of change from entry to suit is a natural one ${ }^{5}$-nothing has been lost on the score of formality.

The same agreement has not always existed as to the manner of termination of a lease for years on condition. Coke's declaration that "a lease for years may begin without ceremony, and so may end without ceremony" and hence that a "lease for yeares ipso facto by the breach of the condition without any entry was void," was taken quite literally by the older authorities, and the principle bade fair to be established that a leasehold on condition is defeasible in the same manner in which all estates on limitation are determinable, that is, by the mere

Ibid.

- (I874) 2r Wall. 44, 63.

"United States v. Repentigny (1866) 5 Wall. 211, 268.

${ }^{8}$ The courts cleaving most to the formal rule ground their view on confession of entry involved in this action: Kenner v. American Contract Co. (1872, Ky.) 9 Bush, 202, 207, 208; Sioux City \& St. Paul R. R. Co. v. Singer (I892) 49 Minn. 30I, 307. Others are governed by statutory changes: Austin v. Cambridgeport (1838) 21 Pick. 215, 224; Cowell v. Springs Co. (1879) 100 U. S. 55,58 . Others have held that since the estate may begin without solemnity, livery of seisin having been abolished, so it may end without solemnity: Ritchie v. Kansas N. \& D. Ry. Co. (1895) 55 Kan. 36, 55. But see Hammond v. Port R. \& A. Ry. Co. (1880) 15 S. C. II, 34; Preston v. Bosworth (I89g) I53 Ind. $458 ;$ Mash v. Bloom (1907) 133 Wis. 646.

'Co. Lit. 214b. Cf. 206b, relied on in Rede v. Farr (I8I7) 6 M. \& S. I2r, to confute the literal reading of this passage. 
happening of the contingency, in this case the breach of condition. ${ }^{10}$ But the practical considerations involved have won the battle over claims of theory, vulnerable as they were, and to-day the contrary is well established.

"In a long series of decisions the Courts have construed clauses of forfeiture in leases declaring in terms, however clear and strong, that they shall be void on breach of conditions by the lessees, to mean that they are void only at the option of the lessors." 11

If the earlier view had obtained the supremacy, any lessee of an estate on condition would be in a position to terminate the lease at his caprice, ${ }^{12}$ and many lessors might have been left remediless or have been put to other means to protect themselves.

One of the reasons given by Coke why entry or claim is necessary to enforce the forfeiture of a freehold on condition, could be applied with as much reason to terms of years on condition. This is that the "feoffor or grantor may waive the condition at his pleasure."13 Here is found the true rationale of the estate on condition. It is an estate defeasible upon the occurrence of a certain contingency at the option of the grantor or his heirs-and, in various jurisdictions, as a result of statute, his assigns..$^{\text {. }}$

\footnotetext{
${ }^{10}$ Penrant's Case (1596) 3 Co. $64 a$.

Second Resolution in Manning's Case (1609) 8 Co. 94b; Wms. Saund. 44I, 442; Leake, Prop. in Land (2d ed.) I7o; Taylor, Landlord and Tenant, s. 492:

"Upon the breach of such a condition in a lease for years, the lease became ipso facto void, and no subsequent recognition [even by the landlord, s. 412] could set it up again. Yet if the condition, in such case, was merely that the lessor might re-enter, the lease was voidable only, and might be affirmed by an acceptance of rent, if the lessor had notice of the breach at the time."

See Kerrick v. Smith (1844, Pa.) 7 Watts \& S. 4I, 47; Parmelee v. Oswego \& S.R.R. Co. (185I) 6 N. Y. 74, 80; Beach v. Nixon (I853) 9 N. Y. 35.

${ }^{u}$ Davenport v. The Queen (1877) 3 App. Cas. II5, I28; Clark v. Jones (1845, N. Y.) I Den. 516; Phelps v. Chesson (1851) 34 N. C. 194; Dermott v. Wallack (1863) I Wall. 6r, 64, 65; Bowman v. Foot (1860) 29 Conn. 33I ; Cartwright v. Gardner (1850) 5 Cush. 273, 28I, in which the change from the old to the modern rule is clearly stated. Sometimes as in Clark v. Jones, supra, it is said that the lease, while voidable as to the lessor, is void as to the lessee. If that were true the lessee would "have no title against any one." But the contrary is the case: Roberts $v$. Davey (1833) 4 B. \& Ad. 664; Blyth v. Dennet (1853) 13 C. B. 178,180 ; see also Porter $v$. Merrill (1878) 124 Mass. 534

1* "In this case, as to this proviso, it would be contrary to a universal principle of law, that a party shall never take advantage of his own wrong, if we were to hold that a lease, which in terms is a lease for twelve years, should be a lease determinable at the will and pleasure of the lessee; and that a lessee by not paying him rent should be at liberty to say that the lease is void."

Lord Ellenborough, C.J., in Rede v. Farr (I8I7) 6 M. \& S. I21, 124

${ }^{13}$ Co. Lit. 218a.

"By statute, rights of entry have been made assignable in England: see 8 and 9 Vict. ch. 106, s. 6; I Vict. ch. 26, 3; also in some states: see Hoyt v. Ketcham (1886) 54 Conn. 60; Southard v. Central R. R. Co. (1856) 26 N. J. I. I3, 2I ; De Peyster v. Michael (I852) 6 N. Y. 467, 506.
} 
The lessor of an estate on condition in case of breach must, then, if he intends to enforce the forfeiture, show his election, either by notice or in some other manner. ${ }^{15}$ Thus, though the acts may differ by which different estates on condition are brought to an end, ${ }^{16}$ they are all subject to the one unifying rule that the act must be one moving from the creator of the interest or his qualified representative or successor. ${ }^{17}$

\section{CONTRASTING PROCESSES}

The enforcement of a forfeiture is distinguished from reverter on the determination of a determinable estate by this supervening act. A determinable estate will revert upon the happening of the contingency, and by that event alone. The reverter takes effect by the "intrinsic force of the limitation" by which the estate is created. ${ }^{18}$ Upon the happening of the contingency, as for instance upon the marriage of a widow to whom land is given during her widowhood, the grantor is seised in law without act or entry. ${ }^{19}$ The ending of the estate or interest is natural-it succumbs to the event; whereas, when an estate on condition is defeated after breach of the condition, it is destroyed by the deliberate act of its creator or his heir. But for this destruction it would have lived on.

The estate on condition is prematurely terminated by the enforcement of the forfeiture. There is only one other form of limitation known to the law (as distinguished from those acts such as tortious alienation, merger, and adverse possession which may destroy estates) by which an estate may be prematurely ended, and that is the executory limitation, whether in its character of executory devise or shifting use. The suggestion of violence done to the estate which is found in the words "premature termination," is borne out in the words employed by most writers who consider executory limitations, and by

\footnotetext{
${ }^{28}$ Leake, Prop. in Land (2d ed.) I70, where the rule is stated without qualifcation. The same view seems dominant in Taylor, Landlord and Tenant, s. 492. In this country a forfeiture for breach of a condition in a lease is usually enforced by an action of ejectment or a summary possessory action. Taylor, op. cit. s. 298; Tiffany, Real Prop. 182.

${ }^{18}$ See Moore v. Ulllcoats Mining Co. [1908] I Ch. 575, 588.

${ }^{17}$ Even in the case of a license subject to a condition it has been held that the license is not terminated by breach of the condition alone, but only upon notice given by the licensor. Roberts v. Davey (1832) 4 B. \& Ad. 664, 672.

${ }^{28}$ Leake, Prop. in Land (2d ed.) I62.

${ }^{20}$ "Seisin in law is the seisin of the heir upon whom the estate in possession descends, or of the remainderman or reversioner whose estate has become the estate in possession by the determination of a precedent particular estate of freehold, before such heir, remainderman, or reversioner, has made an actual entry upon the lands." Challis, Real Prop. (3d ed.) 234.

"Condition defeats the estate, and all remainders depending upon it, and the party or his heir only shall have benefit of it; but limitation determines the estate, and the remainder continues upon it." 5 Vin. Abr. 63 pl. 12.
} 
none more strikingly than Williams..$^{20}$ The executory limitation destroys the estate upon whose defeasance it takes effect quite as truly as the enforcement of the forfeiture destroys an estate on condition. Here also there is a manifestation of supervening force. But it is subjective, existing in contemplation of law. It is instantaneous, automatic-an execution, as it were, by a nicely timed electric shock. Not so the destruction of the estate on condition. There an opportunity exists for pardon, for waiver, even for license to offend, a passing and a forgiving of the breach which may save the offender whole.

The estate on condition continues in right until the entry, but for which it would continue until the utmost period of its direct or collateral limitation, as the case might be. ${ }^{21}$ In this it sharply contrasts with determinable estates and with estates subject to executory limitations. The possession of the tenant of a determinable estate, or an estate subject to executory limitation, originates in right, but becomes wrongful the moment the contingency occurs; for at that moment the estate, if determinable, has come to its natural end, or, if subject to executory limitation, has been abruptly cut off. If the particular estate is a term of years, the tenant holding over may be treated as a tenant by sufferance, and not a disseisor..$^{23}$ Where a tenant pur autre vie holds over, his possession is usually deemed adverse. ${ }^{23}$ Where the grantor of an estate on condition makes entry for breach of the condition, he enters upon a rightful possession, and thereby cuts off or defeats an estate; when he enters upon one who has held over after his estate has determined, or has been cut off by executory limitation, he does not defeat an estate ${ }^{24}$ but merely a wrongful possession. This is so whether the person holding over be regarded merely as a tenant by sufferance, or as a disseisor. The possession of each is tortious, though it may not give an action of trespass before entry $;^{25}$ the relation of neither to the rightful owner gives him an estate.

The difference between entry to enforce a forfeiture and entry to acquire seisin in fact should also be observed. At common law a person having a freehold reversion or remainder is entitled to the possession by the determination of a precedent particular estate of freehold. But he is not clothed with the possession. He is seised in law

${ }^{2}$ Real Prop. (22d ed.) 383-385.

21 Brooke N. Cas. (March's Transl.) 44.

${ }^{2}$ Co. Lit. 57 .

“Doe d. Parker v. Gregory (I834) 2 A. \& E. I4; Tiffany, Real Prop. IOI ; cf. Doe d. Souter v. Hull (1822) 2 D. \& R. 38.

"Even when the possession originates wrongfully, when one actually enters upon the land and ousts the freeholder, he does not acquire, by that act alone, an estate against the real owner. He has a "mere naked possession, unsupported by any right." Butler \& Hargrave's note to Co. Lit. 239a; Leake, Prop. in Land ( $2 \mathrm{~d}$ ed.) 40 et seq.

${ }^{25}$ Co. Lit. 57b, Butler \& Hargrave's note to Co. Lit. $239 a$. 
but not in fact. ${ }^{26}$ To acquire seisin in fact he must make entry. The position of an heir of one who has died, seised in fact of a freehold estate, is similar. To acquire seisin in fact he must make entry, whether it be actual entry or entry in law. ${ }^{27}$ The reversioner, remainderman or heir in such cases must perform an act-not for the purpose, however, of defeating an estate, for the estate is already in him. $\mathrm{He}$ has the immediate freehold. There is no abeyance of the freehold. ${ }^{28}$ The estate was an asset in the hands of the heir, the ancestor having given a bond specifying the heirs, though the seisin was a seisin only in law. ${ }^{28}$ So too, a seisin in law is sufficient to entitle the wife to dower, though it is not sufficient to entitle a husband to curtesy. ${ }^{30}$

The rights of entry of disseisees, including the right of entry of a vested remainderman in consequence of a tortious alienation by the tenant of the particular estate (obsolete to-day because of statutes providing that one can convey no greater estate than he has), while they are not predicated upon a seisin in law, are predicated upon a contemporaneous estate, dormant though it be. A disseisee who makes entry before his right is barred by lapse of time may recover for a trespass committed after the disseisin and before he makes entry. ${ }^{\text {s1 }}$ But one who makes entry for condition broken cannot recover for a trespass committed before his entry. ${ }^{32}$ Again, even before statutes made it possible to devise after-acquired freehold estates, a disseisee might make a devise of lands which would be good if he later made entry. ${ }^{33}$ In contrast with this, the grantor of a fee on condition has nothing which he can devise. ${ }^{34}$

\footnotetext{
28 "Now when his [the particular tenant's] interest is determined, the law supposes the premises to be vacant; (for if the particular tenant continues the possession after the estate ended, it would be a deforcement of the reversioner; which being a wrong on the tenant, the law will not presume;) and upon the determination, therefore, of the particular estate, does the title of entry of the reversioner arise; and the possession being thus supposed vacant, the law presumes it to be in him who has title to enter; and thus has he a seisin in law; for so is his seisin now, and now very properly, called." Watkins, Descents, 39

= Challis, Real Prop. (3d ed.) 236; Watkins, Descents, 63.

${ }^{28}$ Leake, Prop. in Land (2d ed.) 33.

${ }^{29}$ Challis, Real Prop. (3d ed.) 237; Watkins, Descents, 47.

${ }^{20}$ Co. Lit. 31a; Borland's Lessee v. Marshall (1853) 2 Ohio St. 308.

\& It is a "well-known proposition of law that in an action of trespass the right to sue, as against the wrong-doer, relates back after entry to the time at which the right to enter accrued, so as to give a right of action for trespass intermediate in point of time between the date of the right to enter and that of the actual entry." Ocean Accident \& Guarantee Corp. v. Ilford Gas Co. [1905] 2 K. B. 493,497 .

See also Barnet v. Guildford (1855) II Exch. 19; Emerson v. Thompson (I824) 2 Pick 473; Marshall v. Eggleston (1898) 82 Ill. App. 52; Trubee v. Miller (I880) 48 Conn. 347; London v. Bear (I88I) 84 N. C. 266.

- Schulenburg v. Harriman (1874) 21 Wall. 44, 63,64; United States v. Loughrey (I898) I72 U. S. 206; United States v. Tenn. \& C. R. R. (I899) I76 U. S. 242.

I I Wms. Saund. 402.

${ }^{34}$ Jarman, Wills (6th Eng. ed.) 8I ; Challis, Real Prop. (3d ed) 36; Upington
} 
The right of entry on disseisin is sufficient to support contingent remainders, as is also the right of entry of a vested remainderman at common law for tortious alienation. In the latter case, the particular estate is in a sense at an end by the tortious conveyance itself. ${ }^{35}$ Though an entry by the next vested remainderman is necessary to enforce the forfeiture, ${ }^{36}$ the estate conveyed is not the tenant's old estate, but a new estate, a tortious interest. ${ }^{37}$ Still the old estate might be thought of as continuing to subsist in a manner. Thus, to use the words of Challis, this "forfeited estate" would "until entry continue to subsist and support the subsequent contingent remainders,"38 and it would continue for some other purposes. ${ }^{39}$ The entry or continual claim of the vested remainderman served to make this support perfect. His own and subsequent interests are placed in jeopardy by the wrong done to the seisin. The entry removes that jeopardy. How different the entry to enforce a forfeiture on breach of an express condition! That, as we shall see more in detail in the second section following, would, if efficacious at all, operate to destroy the particular estate and all interests depending on it, by substituting the old estate of the entryman.

But more need not be said to emphasize the fact that one who is seised in law, or one who is not seised at all but, being a disseisee or a next vested remainderman, has a right of entry, is in a position materially different from that of an entryman upon breach of condition. The first two made entry to establish a course of descent, or in this and other ways to perfect an estate already in themselves. The last makes entry to defeat an estate now in another, and to substitute therefor an estate once in himself. The rights thus exercised are materially different. The effects of their exercise are not the same. The ultimate consequences of the failure to exercise them, however, are at common law often identical. Alike in some respects, the entry for forfeiture and entry simply to complete or obtain a seisin are wholly unlike in others.

v. Corrigan (I896) ISI N. Y. I43, holding that upon a devise of the residue the right of entry remained in the devisor's heir. In Massachusetts and Kentucky it is held that the right of entry may be devised: Hayden $v$. Inhabitants of Stoughton (1827) 5 Pick. 528; Austin v. Cambridgeport (1838) 2I Pick. 215, 224

${ }^{3}$ Archer's Case (1597) I Co. $66 b$. When the particular tenant and a remainderman for life join in a tortious conveyance, both their estates are forfeited, "because herein the remainder is particeps injurice." Co. Lit. $251 b$.

"Fern v. Snart (1810) 12 East, 444.

"Challis, Real Prop. (3d ed.) 135.

* Ibid. If the first remainder is contingent, it is destroyed at once by the tortious alienation. Only contingent remainders subsequent to the first vested remainder are supported. Archer's Case, r Co. $66 b$.

$\approx$ "But note, reader, that after the feoffment, the estate for life to some purpose had continuance; for all leases, charges, \&c. made by the tenant for life shall stand during his life. ..." Archer's Case, supra, I Co. 66b, 67a. 
Finally, some of the differences between escheat and entry to enforce a forfeiture may be noticed. The lord has his title to the land by the failure of heirs. ${ }^{40}$ In that respect his rights compare with those of one to whom land reverts upon the ending of a determinable estate. It is a title by law. ${ }^{41}$ But to acquire full ownership, he must make entry or sue out a writ of escheat. ${ }^{42}$ In that respect his rights compare with those of one who enters to convert a seisin in law into a seisin in fact. Escheat, while it is a title by purchase, is much like descent, as Blackstone views it. But there is some difference.

"In order to complete this title by escheat," says Blackstone, "it is necessary that the lord perform an act of his own, by entering on the lands and tenements so escheated, or suing out a writ of escheat: on failure of which, or by doing any act that amounts to an implied waiver of his right, as by accepting homage or rent of a stranger who usurps the possession, his title by escheat is barred. It is, therefore. in some respects a title acquired by his own act, as well as by act of

But an heir would not be barred by accepting rent from a stranger who usurped the possession. Such entry by the stranger and acceptance of rent by the heir might give him the very seisin in fact necessary to complete his title. ${ }^{14}$

It is evident that acts similar to those which would merely amount to a waiver of breach of condition ${ }^{45}$-and would not affect the right to enter for a continuing breach ${ }^{46}$-may bar an escheat. In that respect an escheat varies from a condition. Escheat alone gives title, though it be an incomplete one. Breach of condition alone does not.

In Kitchin on Courts Leet we read that" "Where there is Lord and Tenant and the Tenant grants Rent-Charge, and dies without heir general or special, the Lord shall have the Land by Escheat but he shall hoid it charged." But the enforcement of a forfeiture for breach of condition destroys all estates, encumbrances and charges made by the tenant of the estate on condition, subject to exceptions when the condition is one implied in law. ${ }^{48}$

The grantee of a seigniory may enter for escheat. Thus in the little book on conveyancing by Perkins it is declared:

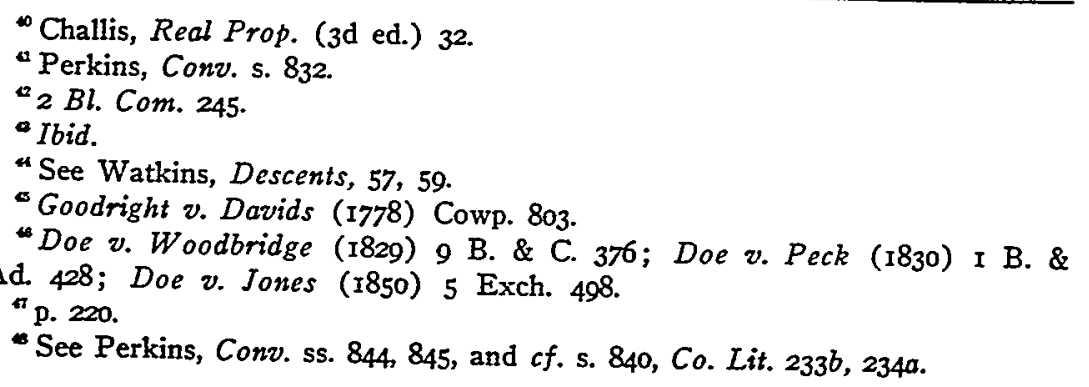


"If lord and tenant be and the lord grant his seigniory for life unto a stranger, and the tenant attorn, and die without heir, and the grantee enters for escheat, he shall not have a greater estate in the tenancy than he had in the seigniory, because the tenancy cometh in lieu of the seigniory." 18

But no grantee, whether of seigniory or reversion, nor indeed a lord to whom a reversion has come by way of escheat ${ }^{50}$ can enter for breach of condition.

"It is a rule of the common law, that none may take advantage of a condition in deed but parties and privies in right and representation, as the heirs of natural persons and the successors of politic persons; and that neither privies nor assignees in law, as lords by escheat; nor in deeds, as grantees of reversions; nor privies in estate, as one to whom the remainder is limited, shall take benefit of entry or re-entry by force of a condition."

The right of entry on express condition, then, is not assignable with the reversion; neither does it escheat with the reversion. It was not an incident of tenure. There being a failure of heirs who could enforce the forfeiture, the right of entry perished. For was it not in this respect like "any other inheritance, that is not holden"? "Because they be not holden, [on failure of heirs] they perish and are extinct by act in law."

\section{DEFEASANCE AND TENURE}

The enforcement of a forfeiture for breach of express condition does not depend on tenure. But estates on condition had their origin in relations of tenure. Thus, we are told by Butler and Hargrave that

"The doctrine of conditions is derived to us from the feudal law. The rents and services of the feudatory are mentioned by feudal writers as conditions annexed to his fief. If he neglected to pay his rent, or perform his service, the lord might resume the fief. But the payment of rent and the performance of feudal services were, for a long period of time, the only conditions that could be annexed to a fief. . . Afterwards, when other conditions were introduced, the estates to which they were annexed, were ranked among improper fiefs. . . . Conditions of this last sort were called express, or conventionary conditions. By an application, in some respects very much forced, of the original principle of conditions, that, on the nonperformance of them, the lord might resume his fief, conditional fees

${ }^{2}$ Perkins, Conv. s. 96.

${ }^{6}$ Though he might enter to distrain. Lit. s. 348.

${ }^{5}$ Southard v. The Central Railroad Co. (1856) 26 N. J. L. I3, 2I; Shepp. Touch. 149.

${ }_{3}$ Co. Inst. $2 \mathrm{r}$. 
at common law, and some other modifications of landed property were introduced as estates upon condition. ${ }^{j}$;3

The services and duties of the tenure itself constitute a condition implied in tenure. The power to enforce a forfeiture for breach of them depends upon tenure. ${ }^{54}$ After the statute Quia Emptores, a right of entry for breach of such conditions could not be reserved by one who conveyed the fee, just because he could not by such conveyance create a new sub-tenure, and the right to enter for breach of such condition remained with the lord of the fee. The situation as to express conditions was the reverse; the right to enter for breach of them the grantor could reserve, independently of tenure, and in consequence the statute Quia Emptores was no obstacle. ${ }^{53}$ Again, the right of a remainderman to enter when the tenant of the particular estate made a tortious alienation of the seisin, this being the breach of a condition implied in the common law, did not, it would seem, (except as he might be said to represent the lord of the fee), depend on a tenure, but on privity of estate.

"Between the owner of the particular estate and the owner of the remainder ... no tenure exists;... . the particular tenant and the remainderman both hold their estates of the same chief lord as the grantor held before."

Such a tortious alienation by the particular tenant was, so to speak, a double $\sin$, a sin against the tenure and a sin against the seisin. It was "a renunciation of the feudal connection" between the particular tenant and the lord of the fee. But it also "devested" the estate of the remainderman, which, if the right of entry was subsequently turned into a right of action, was "discontinued," but not destroyed..5

After the statute Quia Emptores, when one conveyed a fee which might be a fee on condition, he did not subinfeudate. He literally substituted another for himself in the tenancy. The purchaser from him changed places with him, the lord remaining the same. If later the condition was broken and the feoffor entered to enforce the forfeiture, he undid what he had done by the feoffment, and resumed his old

- Co. Lit. $201 a$ note $(84)$.. For a judicial appraisal of Butler, see Heelis $v$. Blain (1864) I8 C. B. N. S. 90, 102.

"Butler's note to Fearne, Contingent Remainders, 382.

Co. Lit. s. 325. Leake, Prop. in Land (2d ed.) 174.

${ }^{86}$ Williams, Real Prop. (22d ed.) 347.

st "In accordance with the maxim that no one can qualify his orem wrong, a tortious feoffment devested the whole fee simple out of the rightful owner or owners. It does not follow that the tortious feoffment was necessarily a feoffment in fee simple; and it might in fact be for a less estate. In such a case, the feoffee took only the less estate, but the whole fee simple was devested out of the rightful owner or owners, and such part of it as was not disposed of by the feoffment became vested in the feoffor by way of a tortious reversion upon the tortious particular estate created by the feoffment." Challis, Real Prop. (3d ed.) 405 , and see $138, n$. 
estate and his old relation to the lord. ${ }^{58}$ In Van Rensselaer $v$. Ball, Denio, J., said :52

"I have been unable to find a single dictum or the slightest hint that such conditions . . . could only be attached to estates for life or years, or that a common law tenure between the parties, or a reversion in the grantors, were necessary to uphold them."

How utterly independent of tenure is the entry for breach is made plain by Littleton's illustration. As he puts it:

"For if a man letteth land to another for term of life by indenture, rendering to the lessor and to his heires a certain rent, and for default of payment a reentry, \&c. if afterward the lessor by a deed granteth the reversion of the land to another in fee, and the tenant for terme of life attorne, \&c. if the rent be after behind, the grantee of a reversion may distrein for the rent, because that the rent is incident to the reversion; but he may not enter into the land, and oust the tenant, as the lessor might have done, or his heirs, if the reversion had been continued in them \&c. And in this case the entrie is taken away forever; for the grantee of the reversion cannot enter, causâ quâa suprà. And the lessor nor his heires cannot enter; for if the lessor might enter, then he ought to be in his former state \&c. and this may [not] be, because he hath aliened from him the reversion."

Where, as in this illustration, the condition is annexed to a particular estate, a grant of the reversion destroys the right of entry at common law quite as effectually as would an attempted assignment of the right of entry itself $;^{\text {:1 }}$ not, however, because the previous relation of landlord and tenant is brought to an end, although that, of course, is true in the case supposed. The rule is the same when the grantor of an estate in fee simple conveys his interest to another. ${ }^{62}$ The conveyance destroys the right of entry, even though it be made by a grantor to his heir, who, but for the conveyance, would have been able to enforce a forfeiture. ${ }^{63}$

${ }^{28}$ Gray, Perpetuities (3d ed.) s. 31.

82 (1859) 19 N. Y. I00, 102.

${ }^{\infty}$ s. 347. See also Perkins, Conv. s. 832.

o The rule so far as estates for years and life estates were concerned was, of course, changed by Stat. 32 Henry VIII, ch. 34, which made it possible for the grantee of the reversion to take advantage of a condition.

"When condition is once annexed to a particular estate, and after by other deed the reversion is granted by the maker of the condition, now the condition is gone." 5 Vin. Abr. "Condition" (I. d. II) ; (2d ed.) 306.

I Shepp. Touch. 157, 158, Lit. s. 325, Leake, Prop. in Land (2d ed.) I74.

"Neither party to a conveyance which violates the rule of law can allege his own unlawful act for the purpose of securing an advantage to himself. The grantor of a right of entry cannot be heard to say that his deed was void, and that the right of entry still remains in him, because this would be to allow him to set up his own turpitude in engaging in a champertous transaction as the foundation of his claim. His deed is therefore effectual to estop him from setting up its invalidity as the ground of claiming a right of entry which he 


\section{THE EFFECT OF DEFEASANCE UPON THE ESTATE LINE}

Whenever there is an entry to enforce the forfeiture of a freehold estate for breach of condition, the entire state line which was supported by the estate on condition, is broken down, and a former estate line is re-established.

For, as Littleton says, "then may the feoffor or his heires enter into such lands or tenements, and them in his former estate to have and hold." In the ordinary case, the feoffor or his heir is in of the feoffor's former estate as though the feoffor had never parted with it. And even in the exceptional case, in which the entry served to vest a former estate in another, ${ }^{65}$ or to give the entryman a legal estate where before he had an equitable, ${ }^{66}$ or a tenancy in tail after possibility of issue extinct. where before he had a fee tail, ${ }^{67}$ at common law the entire estate on condition is broken down. And this would mean destruction of any future interests dependent on it for support.

had unlawfully conveyed. Nor can the grantee avail himself of the right of entry for a like reason. He cannot be permitted to set up a title which rests upon a conveyance which he has taken in contravention of the rules of law Both parties are therefore cut off from claiming any benefit of the condition. The grantor cannot aver the invalidity of his own deed, nor can the grantee rely on its validity. Both being participators in an unlawful transaction, neither can avail himself of it to establish a title in a court of law." Rice $v$. Boston $\&$ Worcester R. $R$. (I866) I2 Allen, I4I, I44.

Lit. s. 325.

"When a man seised of land in right of his wife conveyed in fee on condition, and died, the heir might enter,

"but it is impossible for him to have the estate that the feoffor had at the time of the condition made. ... And therefore when the heire hath entred for the condition broken and defeated the feoffment, his estate doth vanish, and presently the state is vested in the wife." Co. Lit. 2020.

Similarly an heir ex parte paterna would enter to enforce a breach for the benefit of an heir ex parte materna. Shepp. Touch. 150, concerning which Preston says:

"The first is heir to the person and the condition; the other is heir to the estate. The position is peculiar to grants in fee and is an anomaly. ... It is a actum agcre."

"s "If Cestuy que use after the statute of $R .3$, and before the statute of $27 \mathrm{H}$. 8 , had made a feoffment in fee upon condition, and after had entred for the condition broken; in this case he had but an use when the feoffment was made, but now he shall be seised in of the whole state of the land ... for by the feoffment in fee of Cestuy que use, the whole estate and right was vested out of the feoffees. And therefore of necessitie the feoffor must gain the whole estate by his entrie for the condition broken." Co. Lit. 202a.

The Statute I Rich. III, ch. I, here referred to, gave the cestui gue use a direct power of conveying the legal estate. See Leake, Prop. in Land (2d ed.) 80. For a case after the Statute of Uses in which it was applied see Dyer $283 a$. It was "not positively repealed until 1863, when it had for ages been quite obsolete. . . This statute never had any extensive operation." Challis, Real Prop. (3d ed.) 386.

${ }^{\sigma}$ Co. Lit. $202 a$. 
"The estates of both the parties," says Sheppard's Touchstone, "are so suspended [i.e., affected] by the condition that neither of them alone can well make any estate, or charge, of or upon the land: for the party that doth depart with the estate, and hath nothing but a possibility to have the thing again upon the performance or breach of the condition, cannot grant or charge the thing at all. And if he that hath the estate, grant or charge it, it will be subject to the condition still; for the condition doth always attend and wait upon the estate or thing whereunto it is annexed: so that although the same do pass through the hands of a hundred men, yet is it subject to the condition still ..... And when the condition is broken or performed, \&c. the whole estate shall be defeated."

In order to grasp the full effect upon the estate line of the entry. something more is necessary. Here, if anywhere, the conception of each estate line as a distinct entity, or plane of ownership, dependent upon a particular seisin, becomes of importance. As Watkins says:

"A remainder is to commence when the particular estate is, from its very nature, to determine; it is, as it were, a continuance of the same estate; it is a part of the same whole ... The particular estate and remainders are, in fact, (as the very terms imply), but one and the same estate."

And this whole of which the particular estate and each remainder is but a part, may be thought of, as Pollock and Maitland conceive of it, as "an infinite quantity."

"Proprietary rights in land are, we may say, projected upon the plane of time. ... The life-tenant's rights are a finite quantity; the fee-tenant's rights are an infinite, or potentially infinite, quantity." "7o

If $A$ conveys to $B$ for life on condition that he shall not marry $C, B$ is seised. He represents the fee. His seisin is, so to speak, the root of the estate line. ${ }^{71} \mathrm{He}$ is seised in representation of $\mathrm{A}$ who has the reversion in fee, and who is "in the seisin of the fee," but who is actually seised neither in fact nor in law, and who until a breach of the condition has not even a right to enter. What occurs when the

\footnotetext{
'Shepp. Touch. I20.
}

"Descents, 210. "The particular estates, and the ultimate remainder all together formed one tenure of the fee of the lord." Fearne, Cont. Rem. 298, Butler's note (2).

${ }^{70} 2$ Poll. \& Mait. Hist. Eng. Law (2d ed.) Io.

${ }^{7}$ It is permissible to think of one estate being derived out of another. Thus, Challis speaks of the case "when a number of successive vested estates of freehold are derived out of the same original estate." Real Prop. (3d ed.) 99. Or life estates and estates tail may all be thought of as parts of the absolute interest, which in one aspect is the fee, in another the seisin. "The particular estate and the remainder, to many intents and purposes, make but one estate in judgment of law." Co. Lit. 143a. See also Watkins, Descents, 36. 
condition is broken and $A$ re-enters? Immediately the seisin of $B$ is destroyed and A becomes seised. His seisin is substituted for B's; it does not flow out of B's as it would if B's estate had terminated naturally. B's estate has become "as nothing from the first."

\section{v. REMAINDERS}

The same reasoning applies, but its exposition becomes more complex, when remainders are involved. Thus, to take an illustration from Fearne:

"It seems," he says, "that if an estate be granted to A, a widow for life, remainder to $B$ in fee, on condition that $A$ continues a widow; if A marries, the entry of the heir defeats the estate to $A$ and to $B$ also." For, as he says on the page just preceding, "the livery made upon the creation of the estates is defeated, and of course every estate then created is thereby annulled and gone."7s

The remainder of $\mathrm{B}$ depends upon and is supported by the particular estate in A. His is the root of B's interest which can take effect only in case the root is not destroyed, as it must be when the grantor or his heir enters, prematurely ending A's interest. Unlike a disseisin, ${ }^{74}$ the effect of this entry is permanent. It absolutely destroys the estate line and if the former tenant of the particular estate again obtains title to the land, it must be as of a new estate. ${ }^{35}$ It has been held that the remainderman has no relief in equity; he cannot compel the tenant for life to perform a condition. ${ }^{78}$ Of course the cases must be distinguished where the so-called condition is held to create an equitable easement $^{77}$ or a trust, ${ }^{78}$ for when this is so, the parties interested may generally secure its performance.

\footnotetext{
"Cont. Rem. 262. Apparently Fearne (his wording is unlike the similar illustration in Sanders, Uses, I57) intends a remainder which is not limited independently of the condition. Otherwise it would be impossible to reconcile what he says on p. 270. See also Leake, Prop. in Land (2d ed.) I73; Williams v. Angell (I862) 7 R. I. I45, I52.

"Ibid. 261. "And if a lease be made for life, the remainder in tail, on condition; in this case if the condition be broken, both the estates be avoided." Shepp. Touch. I55.

7" See Leake, Prop. in Land (2d ed.) 40 et seq.

"See Jones v. Carter (1846) I5 M. \& W. 718.

${ }^{70}$ Kinnersley v. Willianison (1870) $39 \mathrm{~L}$. J. Ch. 788. The court said that it had no jurisdiction, the estates being all legal.

$"$ Ayling v. Kramer (1882) 133 Mass. 12; Jewell v. Lee (I867) I4 Allen, I45; Fuller v. Arms (1873) $45 \mathrm{Vt} 400$.

${ }^{78}$ West v. Biscoe (1825, Md.) 6 Harr. \& J. 460; Tomlin v. Blunt (I888) $3 \mathrm{I}$ IIl. App. 234. See the extended consideration in Gray, Perpetuities ( $3 \mathrm{~d}$ ed.) s. 282 , n.
} 
"But ... though an entry made for breach of condition will destroy the remainder, yet the remainder is not void in its inception; and it is not destroyed by a breach of condition, unless an entry is made for the breach. If the person entitled to enter for the breach waives his right of entry, the particular estate continues in being; and upon its subsequent regular determination, the remainder will take effect."

These are Challis' words. ${ }^{79}$ He speaks of the remainder here as a remainder "limited to commence upon the defeasance of the particular estate," but it seems apparent from the part quoted above, and from his reference to Fearne and Preston, ${ }^{80}$ that while he may mean a remainder which the grantor or devisor intended to "commence" in possession upon the defeasance of the particular estate, he is thinking of a true remainder,-one, therefore, which may "commence" in interest before the natural termination of the particular estate. If the defeasance were a condition precedent to the vesting, the remainder would be void. ${ }^{81}$ In Fearne's illustration the remainder is vested from its creation, and as he says: "A remainder properly so called, cannot be limited to take effect upon a condition which is to defeat the particular estate."82 A contingency serving to determine an estate cannot also operate as condition subsequent. ${ }^{83}$ Neither Fearne nor Challis is speaking of a shifting use or a "shifting" executory devise-limitations which always take effect in derogation of a prior interest, whether it be fee or particular estate-but of a remainder dependent on a condition subsequent annexed to the preceding estate and in effect to the remainder; dependent not for its commencement, be it emphasized, but for its continuance. Leake says:

"At common law if the land be limited for a particular estate with remainders, subject to a condition, the re-entry defeats all the estates in remainder, as being dependent upon the seisin of the particular estate." 84

Real Prop. (3d ed.) 82. See also Williams v. Angell (1862) 7 R. I. 152.

- They are Fearne, Cont. Rem. 270; I Preston, Estates, 9r.

autler \& Hargrave's note to Co. Lit. $203 \mathrm{~b}$ gives the reasons clearly.

- Cont. Rem. 26I, I Preston, Estates, 9r. And see Plowd. 29a, Lit. s. 723.

${ }^{3}$ If a condition is annexed to a determinable estate, purporting to defeat the estate in the same manner which determines it by the original limitation,

"as in the case of a gift to a man in tail, and if he die without hcirs of his body, that then the donor and his heirs shall re-enter, [this] would be inoperative and therefore a void condition." Ieake, Prop. in Land (2d ed.) 168.

"For if a gift in tail be made to a man and to the heirs of his body, and if he die without heirs of his body, that then the donor and his heirs shall re-enter, this is a voyd condition; for when the issues fail, the estate determineth by the expresse limitation, and consequently the adding of the condition to defeat that which is determined by the limitation of the estate, is void." Co. Lit. $224 b$.

"Prop. in Land (2d ed.) 173, referring to Fearne, Cont. Rem. 261, 262, and I Sanders, Uses, I52. 
Probably this is the truest way of putting it. For whatever the form in which the limitations are expressed, one common-law interest will not be affected by the condition unless all subsequent remainders are affected by it.

When the limitation of a particular estate is such that in order to secure the rent, it "merely gives an entry and retainer without defeating the particular estate," it is not a true condition, and the remainder would not be affected by the entry. ${ }^{85}$ So far from enforcing a forfeiture, such entry is either a holding of lands as a pledge until the rent is paid, or a taking of the profits in satisfaction of the rents. ${ }^{8 B}$ In equity it is the latter only. 87 The distinction between a right of mere entry and retainer and a right of entry to enforce a forfeiture could not be more sharply emphasized than by the immediate juxtaposition of the sections on these subjects in Littleton. ${ }^{88}$ Speaking of the right of mere entry and retainer, Coke, giving the pertinent passage from Littleton, says:

" For in this case the feoffor shall have the land but in manner as for a distresse, until he be satisfied of the rent, \&c.' By this it appeareth that the feoffor by his re-entry gaineth no estate of freehold, but an interest by the agreement of the parties to take the profits in the nature of a distresse." 89

If a remainder is limited over independently of a condition to which a particular estate is made subject-that is, without any reference to the condition-according to the better and more general opinion, the condition itself is repugnant and void. ${ }^{.0}$

"It is unreasonable," says Fearne, "that the grantor should defeat the estate in remainder, which he had absolutely granted away. Indeed it seems directly within the reason of the cases put by Littleton, that a man lease for life upon condition of re-entry for default of payment of rent, and the lessor afterwards grants his reversion, the lessor or his heirs cannot enter, because he hath aliened the reversion; so in

See the criticism and distinction by Preston in his Shepp. Touch. I20.

Cruise, Dig. Tit. XXVIII, ch. I, ss. 68, 70.

"Ibid. s. 69.

ss. $326,327,328$.

${ }^{80} \mathrm{Co}$. Lit. $203 a$. "This is so. though the condition be, that the feoffor, his heirs and assigns, may enter; and his interest goes to his executor. But he may maintain an ejectment. I Saund. I12. I Sid. 344, 345, T. Raym. I35, I58."Butler and Hargrave's note (2) to Co. Lit. $203 a$.

"When a condition is annexed to a preceding estate, and the remainder is limited to commence, substantively, on the determination of that estate, indepem dently of the condition, the condition will -be discharged, and the estate of the particular, tenant become simple and absolute." I Preston, Estates, 9I.

See Fearne, Cont. Rem. 270; Sanders, Uses, r55; Challis, Real Prop. (3d ed.) 81, 82; Leake, Prop. in Land (2d ed.) 173. Butler may have entertained a different view: see his note to Fearne, Cont. Rem. 383. And see Lit. s. 723; Willians v. Angell (1862) 7 R. I. I45. 
the above case the lessor by limiting the remainder over absolutely, hath departed with the reversion, as much as if he had afterwards aliened it by another conveyance." ${ }^{, 91}$

It would follow that a condition annexed as well to any remainder except a remainder of the fee or a remainder immediately preceding a reversion, would be subject to the same considerations. If it is a remainder in fee or a remainder preceding a reversion, the condition, since it has its usual and normal operation and is not repugnant to any estate granted over, could be enforced. ${ }^{22}$ If the condition annexed to the remainder is broken before the particular estate determines, the forfeiture may none the less be enforced-by a claim at common lawbut the enforcement has no effect on the particular estate. ${ }^{93}$

It seems that the enforcement of the forfeiture of a remainder, vested or contingent, for breach of a condition subsequent, when operative at all, will have the same effect on subsequent common-law interests that entry for forfeiture of a particular estate in possession would have.

Assume that a condition is annexed to the first remainder alone, and that a second remainder is limited without reference to the condition. Assume that the condition is not broken until the first remainder becomes an estate vested in possession. Can its forfeiture be enforced, thus destroying the second remainder? It would seem not, since the subsequent remainder was limited over independently of the condition. The condition must be treated as repugnant and void.

On the other hand, where the second remainder is not limited independently of the condition annexed to the preceding remainder, where in other words it is subject to the same condition, the enforcement of the forfeiture of the first remainder, whether. this takes place while it is still a remainder or after it becomes an estate in possession, will destroy that and the second remainder. Land is granted to A for life, remainder to $B$ for life on condition subsequent that he continue to comply with stipulated requirements, remainder to $C$ and his heirs on the condition that $B$ continue to comply with the requirements aforesaid. Before A dies, B commits a breach and the grantor makes claim. Has $\mathrm{C}$ any interest remaining?

Would it be overbold to suggest that the following rule, though apparently it has not been clearly formulated by any authority, is a necessary corollary from what has been said? To wit: In order that the forfeiture of a remainder for breach of condition may be enforced,

Fearne, Cont. Rem. 270. Lit. s. 723 is here ignored by Fearne.

"2 See Shepp. Touch. (ed. by Preston) rzo.

"A condition may avoid a remainder, without defeating the particular estate." Shepp. Touch. (ed. by Preston) I2I. "A condition may be annexed to a remainder without affecting the prior estates." Id. I55. See also Shepp. Touch. (8th ed. by Atheling) r55, n. (i). 
all subsequent remainders as well must be made subject to the condition. Either this must be admitted or the doctrine that a condition fails when it would defeat a remainder not limited in reference to it must be abandoned.

It is true that, generally speaking, the failure of a prior remainder to take effect will not prevent a subsequent remainder from taking effect. The first estate is considered "only as a preceding limitation, and not as a preceding condition, to give effect to the subsequent limitation." 94 When there is a clearly expressed intent to the contrary, the rule seems otherwise. ${ }^{95}$ It is also true that the contingency affecting the vesting of a prior estate has no effect on a subsequent remainder vested or contingent unless it is intended to have some effect. ${ }^{98}$ But these admitted rules do not confute the proposition that a remainder, however remote, which is subject to a condition affecting a preceding interest or interests will be defeated by the enforcement of a forfeiture. In such a case the grantor or devisor intends that the remainder shall be affected by the condition. After the formidable arguments and opinions in Egerton v. Brownlow, buttressed as that case is, it should be regarded as fundamental that a condition subsequent can be annexed even to a contingent remainder, and operate to defeat it before it has become a vested interest.

"I know, by the authorities which have been referred to," said Lord St. Leonards in that case, "that conditions which were intended to defeat an estate have defeated an estate in contingency just as much as a vested estate." ${ }^{\prime 97}$

In In re Viscount Exmouth the court said: "Such contingent limitations in the way of defeasances are, in my view, subject to all the rules which apply to conditions subsequent." ${ }^{98}$

Williams v. Jones (I90I) I66 N. Y. 522, 537. This language is like that in Fearne, Cont. Rem. 508, and see 233 et seq.; Goodright v. Cornish (1693) I Salk. 226; Jarman, Wills (6th Eng. ed.) 718 et seq.; Theobald, Wills (7th ed.) 790.

8 "This doctrine of acceleration, however, . . . is applied in promotion of the presumed intention of the testator, and not in defeat of his intention. And when it is the evident intention of the testator that the remainder should not take effect till the expiration of the life of the prior donee, the remainder will not be accelerated." Blatchford v. Newberry (I880) 99 III. II, 48 . See Reeves, Rcal Prop. II93, II94.

${ }^{*}$ Fearne, Cont. Rem. 233 et seq.; Ranken v. Janes (1896) I N. Y. App. Div. 272. But the contingency affecting the prior interest may prima facie apply to the whole series of limitations. See Theobold, Wills (7th ed.) 578, and cases cited.

"(1853) 4 H. L. Cas. I, 208; In re Greenwood [1903] I Ch. 749; Gingrich v. Gingrich (I896) I46 Ind. 227; Kelso v. Lorillard (I88I) 85 N. Y. I77, I84. And see Edwards v. Hammond (1694) 3 Lev. 132.

${ }^{2}$ (1882) $23 \mathrm{Ch}$. D. 158, I64 A remainder may also be made determinable on a contingency which may happen before the particular estate determines: Lambarde v. Peach (1859) 4 Drew. 553, 559, 560; Re Muggeridge's Trusts (1860, Eng. Chanc.) I Johns. 625. 


\section{REMIAINDERS BY WAY OF DEVISE}

It may be that in a will a condition can be annexed to the particular estate only and a forfeiture be enforced without affecting the remainder. Leake alone among modern text-writers expressly embraces this doctrine-in the semi-obscurity of a foot note- ${ }^{09}$ though it must be said at once that if others reprobate the rule, they do so perhaps inferentially.

The authority for the proposition is the case of Warren $v$. Lee $e^{100}$ decided about I555, some ten years after the Statute of Wills.

"And it seems," said the court in that case, "that the remainder is not destroyed by the entry, but the heir shall have only an estate for the life of the wife [to whom the husband had devised for life on condition that she should provide for and educate their eldest son until he attained the age of 21 , remainder to the second son in tail] ; for there is a difference between this remainder made by will, and a remainder created by deed and livery; for in the last case the entry defeats the livery; but it is not so in a will, for a remainder by will is good, although the particular estate was never good; as if to a monk, \&c. ${ }^{101}$ And the law in this case shall be taken in the same manner as if the devisor had expressly reserved an entry and retainer during the life of the wife; and such tempering and qualifying of the penalty

"Prop. in Land (2d ed.) 173 n. (k); also in Ist ed. $23 \mathrm{I}$ n. (b).

in (1555) 2 Dyer, $126 b, 127 b$.

:o Perk. Conv. ss. 567,568 where such limitations by wills and conveyances at common law are sharply distinguished. To the same effect is the comment of Preston in his Shepp. Touch. 435:

"The reason given ... is, that a monk is civiliter morturu, and that the effect is the same as if the devise had been to a person who had died in the lifetime of the testator."-Lomas $v$. Wright (1833) 2 Myl. \& K. 769, 779.

The doctrine involved in such a limitation by will has come to be recognized as that of acceleration: Jarman, Wills (6th Eng. ed.) 718, citing Perk. s. 567.

"In the case of a devise to a person for life with remainder in fee, where the tenant for life is incapable of taking or is not in rerum natura, the remainder is valid and (if vested) will be accelerated."-Theobald, Wills (7th ed.) citing Perk. ss. 566, 567, and Year Book 9 Henry VI, fo. $24 b$.

Is it sufficiently established that the doctrine of acceleration of the vested remainder on avoidance of the particular estate applies only to wills? The decided cases, while they seem confined to wills, do not expressly remark any difference between wills and deeds, and apparently some of the judges may entertain an opinion that there is no difference. See Jull v. Jacobs ( 1876$) 3 \mathrm{Ch}$. D. 703, 7II, 712; Key v. Weathersbee (1894) 43 S. C. 414, 424, 425; Lainson v. Lainson (1853) I8 Beav. I; Dracus v. Crump (I846, Ky.) 6 B. Mon. 363. Modern texts, such as those of Williams, Challis, Leake, and Washburn, pass over the question. Some state the law of acceleration in such terms as to include remainders by deed as well as by devise: Tiffany, Real Prop. 304. See also Fearne, Cont. Rem. 308, Cruise, Dig. Tit. XVI, ch. IV, ss. 17, 18. Lord Hardwicke in Avelyn v. Word (1750) I Ves. Sr. 420, said that he knew

"no case of a remainder or conditional limitation over of a real estate, whether by way of particular estate so as to leave a proper remainder, or to defeat an 
shall not altogether defeat the estate, \&c. as Litt. (\$. 327) says of re-entry and retainer until, \&c. which is only in lieu of distress or pledge, \&c."

The decision is not mentioned in Fearne, Coke upon Littleton, or Challis, the other leading texts in which, if anywhere, we might expect to find an authoritative recognition of it. ${ }^{102}$ The reference to the case in Sheppard's Touchstone at page I2O is ambiguous. Preston so treats it. Why then have such writers given the decision a wide berth? Have they scouted the decision as a piece of unwarranted judicial legislation? The case, literally taken, would convert an unqualified condition in a devise-at least where there are remainders-into a mere entry and retainer, which both Littleton and Coke treated as something absolutely different. ${ }^{103}$

It may be that the explanation is in part to be found in a feeling that the decision is not to be reconciled with the many cases in which it has

absolute fee before by a conditional limitation; but if the precedent limitation, by what means soever, is out of the case, the subsequent limitation takes place"

But see Lord Stafford's Case (16ro) 8 Co. 75, and Crabb, Real Prop. 639.

No authoritative and apposite discussion of the doctrine of seisin involved in the distinction has been found. A devise gives seisin in deed to the remainderman in such a case. Livery of seisin to a termor for years confers the seisin upon the vested remainderman (Lit. s. 60) who takes an immediate vested estate.

It "is not a remainder strictly so called; for the lease for years does not interfere with or affect the limitation of the freehold title."-Leake, Prop. in Land (2d ed.) 231. 654

It is "a present estate subject to the term."-3 Jenks, Dig. of Eng. Civil Law,

"Livery of seisin may be given and received by attorney. But the authority to give or receive livery must be by deed."-Cruise, Dig. Tit. XXXII, ch. IV, s. 14. See Lit. s. 66; Co. Lit. 51 b, 52a.

"A man being absent cannot take a freehold by a livery, but by his attorney being lawfully authorised to receive livery by deed, unlesse the feoffment be made by deed, and then the livery to one [under certain circumstances] in the name of both is good."-Co. Lit. 496 .

But could the person to whom livery of a particular estate void in law had been made be regarded as in the position of a bailiff of the remainderman (Williams, Real Prop., 22d ed., 348) as in the case of a lessee for years? He would take no interest in the land. And since he would have no authority by deed to receive livery of seisin in behalf of the remainderman, could the livery to him as attorney be of any effect? It might be said to-day-and no doubt some courts would say-that livery of seisin having been abolished or become obsolete, there is no reason why the doctrine of acceleration of a vested remainder on avoidance of the particular estate should not apply to deeds as well as to wills. Deeds to-day by statute, independently of the Statute of Uses, frequently give seisin in fact.

${ }^{100}$ And it may be added that there is no mention of it or of the rule involved, in Cruise, Dig., in Williams, in Crabb, in Halsbury, Lazes of Eng., Jenks, Dig. of Eng. Cizil Lazi, Jarman, Wills,-except in an addendum to the 6th Eng. ed. by the editor, Sweet, who cites it merely in the statement that a devise may be subject to a condition.

${ }^{203}$ Lit. ss. 325, 327; Co. Lit. 202a, 203a, and Butler and Hargrave's note (3); Crabb, Real Prop. s. 2193; Cruise, Dig. Tit. XXVIII, ch. I, ss. 68, 69, 70. 
been held that devises by way of remainder are subject to the same incidents as common law remainders.

"Under the Statute of Uses and Wills," says Professor Gray (he too makes no mention of Warren $v$. Lee) "remainders created by way of use or by devise had all the incidents of remainders created by common law, but under those statutes future estates could be created which were not remainders and which could take effect without regard to any preceding estate."104

Perhaps not a few have been influenced by certain considerations such as the time of the case, which was the formative period of the executory devise. In any event, it is of interest to note that as recently as 1870 , in the case of Kinnersley $v$. Williamson, ${ }^{105}$ it was declared by counsel and not denied by the court-though the point was not passed upon-that an entry by the heir for breach of a condition annexed to a particular estate created by devise would defeat the remainders.

\section{VIT. INDEPENDENT IIMITATIONS}

Whenever a freehold limitation arises independently of a preceding estate, if of the shifting type, it will operate to defeat the preceding estate; if of the springing type, it will take effect regardless of the fact that a forfeiture of a preceding estate has been enforced. Shifting uses and executory devises that shift the seisin are thus more than independent of preceding estates; by their supervention they destroy the preceding estates. Springing uses and executory devises of a like character are totally independent of the seisin of preceding interests, whether such preceding interests are created with them at the same time, or are afterwards substituted as the result of an entry to enforce a forfeiture. Indeed, they may be said to operate in destruction of such substituted estates in the same manner as a shifting use or a shifting executory devise does. ${ }^{108}$

Obviously, the practical consequences of this independence of preceding limitations are of the first importance. It is an independence which unfetters the hands of any one who would create a future freehold, and, provided he is careful not to give his limitations the form

${ }^{104}$ Perpetuities, s. 919, and see generally ss. 918, 926; also Leake, Prop. in Land (2d ed.) 257 ; Doe v. Scudamore (I800) 2 B. \& P. 289, Purefoy v. Rogers (ca. I683) 2 Wms. Saund. 380, 382. See Challis, Real Prop. (3d ed.) 17r, 172.

${ }^{100} 39$ L. J. Ch. 788.

${ }^{100}$ And therefore like the operation of a springing use on a resulting use. "The springing use thus operates upon the resulting use in the same manner as a shifting use does upon the preceding limitation, and does not operate by way of remainder." Leake, Prop. in Land (2d ed.) 254 
of remainders, ${ }^{107}$ makes it possible for him to annex a condition to any interest present or future without jeopardizing other future interests, and without subjecting such interests to the condition. A can devise to $B$ and his heirs upon condition subsequent, and he can provide that upon an entirely distinct contingency thereafter occurring the property shall go to $\mathrm{C}$ and his heirs. ${ }^{108}$ Or he can convey to uses in the same way. ${ }^{108}$ If the condition is broken, there may be an entry and enforcement of the forfeiture. If later the second contingency occurs, $\mathrm{C}$ becomes seised in fee. In each case, what the testator or grantor had intended has occurred.

Substantially the same freedom is possible in the creation of terms of years in futuro by tenant in fee simple or fee tail. We may have limitations of terms of years in the form of remainders. But they are not true remainders. They are not parts of one estate created by livery or its modern equivalent and dependent on the particular estate for support. They are "related in the order of their enjoyment" by no imperative rule of the common law but "only by the terms of the contract or contracts that create them." In holding that a limitation in form a remainder for years depending on an estate for years cannot be a remainder, it was said in Corbet $v$. Stone ${ }^{110}$ that

"A lease for years operates by way of contract, and therefore the particular estate and the remainder estate [so called] operate as two distinct estates grounded upon several contracts; but it is true, such a remainder may be of a freehold, as upon an estate for life, . . . and then in law the particular estate, and the remainder, is but one estate in law, and is created by livery."

A may give a series of leases of the same land creating all of them at different times or at the same time.111 The latter only would be possible if they were deemed remainders. ${ }^{112}$ If then $A$ gives a series of leases, the first to $B$ for five years, then to $C$ for five years, then to $D$ for five years, the grants to $C$ and $D$ are "not remainders, but grants

${ }^{100}$ "It is a well-known rule . . that no limitation capable of taking effect as a contingent remainder shall, if created inter vivos, be held to be a springing use under the Statute of Uses, or, if created by will, be held to be an executory devise under the Statute of Wills or the Wills Act, 1837." White v. Summers [1908] 2 Ch. 256, 262.

See also Doe v. Scudamore (I800) 2 B. \& P. 289; Hawes v. Hawes (1880) I4 Ch. D. 614. See the comment on Simonds w. Simonds (Ig08) I99 Mass. 552, in Gray, Perpetuities, ss. 918-926.

${ }^{208}$ As to the untrammeled nature of executory devises see Challis, Rea: Prop. (2d ed.) 169 et seq. See Jarman's definition, Wills (6th Eng. ed.) 1432 .

"wee Rogers v. Eagle Fire Co. (1832, N. Y.) 9 Wend. 611; Roe v. Tranmer

(I757) 2 Wils. C. P. 75; Davies v. Speed (1692) 2 Salk. 675.

${ }^{110}$ (ca. 1678) T. Raym. 140, I5I.

211 "If a man makes a lease for years to begin at Michaelmas next ensuing, it is good." Barwick's Case ( 1597 ) 5 Co. $93 b, 94 b$.

"Co. Lit. I43a; Leake, Prop. in Land ( $2 \mathrm{~d}$ ed.) $23 \mathrm{I}$. 
to commence in futuro, independent of the preceding grant or grants."113

It follows that each of the leases may be subject to conditions the enforcement of which will destroy the interest in question without affecting the other interests. And although the leases in futuro be limited without reference to the conditions annexed to preceding leases, such conditions would be enforceable. They do not prejudice the later leases, hence they could not be deemed repugnant; and since the Statute of 32 Henry VIII, ch. 34, it is possible for the grantee of the reversion to avail himself of the conditions annexed to leases for years (as for life).

Excepting the rule against perpetuities, there is only one important restriction upon this broad freedom in the creation of leaseholds in futuro subject to conditions. The rule that a life estate is greater than any term of years is of such potency that at common law if a lessee attempts to grant his term to A for life, with remainders over, $A$ will take the entire term. ${ }^{114}$ Conditions annexed to the so-called remainders could therefore have no operation. Only conditions annexed to the limitation for A's life would be of any effect. If forfeiture were enforced, the grantor would be in of his original term unaffected by the terms in futuro.

But it is quite possible that a different rule will come to obtain in the United States, ${ }^{115}$ for at present there seems to be practically no American authority on the matter. ${ }^{118}$ Our courts for the most part have been untrammeled in their dealing with future limitations of chattels personal; they have held that interests for life with limitations in futuro can be created by deed as well as by will. ${ }^{117}$ A similar attitude

${ }^{11}$ Gray, Perpetuities (3d ed.) ss. 7I, 32I.

w" A termor reciting by indenture his term and lease, granted all his term estate and interest to another, habendum to him and his assigns immediately after the death of the grantor... the case was ruled, and adjudged, that the habendum was void, and the premises of the grant good to make the entire term pass to the grantee immediately."-Lilley v. Whitney (I568) Dyer $272 a$. See Welcden v. Elkington (1578) Plowd. 5I6, 519, 520.

See Leake, Prop. in Land (2d ed.) 232. But the termor may effectively grant his leasehold to be held after the death of a stranger to whom no interest is given. It is not presumed that the stranger will not die within the term. Rayman v. Gold (ca. 1592) Sir Francis Moore, 635. See Gray, Perpetuities, s. 81o.

Moreover, "to get out of the literal authority of old cases, an ingenious distinction was invented: a remainder might be limited for the residue of the years; but not for the residue of the term." Lord Mansfield in Wright v. Cartwright (1757) Burr. 282.

${ }^{115}$ Gray, Perpetuities, ss. 71 $b, 8 \mathrm{I} 6$.

${ }^{110}$ In Culbreth v. Smith (I888) $69 \mathrm{Md}$. 450, the court was strongly of the opinion that a life interest could be created by deed in any leasehold estate, with limitations over. See Gray, Perpetuities, s. $7 \mathbf{I}$.

${ }^{117}$ Duke v. Dyches (1848, S. C.) 2 Strobh. Eq. 353 n.; Brummet v. Barber (1834, S. C.) 2 Hill, 543 ; Gray, Perpetuities, ss. 78, 92, 854 
toward chattels real would insure a similarly fortunate result. Ever since Manning's Case ${ }^{118}$ it has been held that a bequest of a term to one for life, remainder over, would achieve its purpose. There would seem to be no reason why such limitations by way of will,-and by deed if they should be sustained,-could not be subjected to conditions with freedom and certainty of result. ${ }^{118}$

${ }^{218}$ (16ro) 8 Co. 94b; Cotton v. Heath (1638) I Rolle Abr. 612, pl. 3, translated in 5 Gray, Cases on Prop. (2d ed.) II7.

210 See the covenants, etc, of the lessees in Wright $v$. Cartwright (1757) I Burr. 282. In Manning's Case, supra, it was said: "This devise is but of a chatte! [real] ... and which may vest and revest at the pleasure of the devisor, without any prejudice to any." 